\title{
REVIEW
}

\section{Key signaling nodes in mammary gland development and cancer: $\beta$-catenin}

\author{
Angela Incassati ${ }^{1,2}$, Anupama Chandramouli ${ }^{1,2}$, Rachel Eelkema ${ }^{1,2}$ and Pamela Cowin ${ }^{1,2 *}$
}

\begin{abstract}
$\beta$-Catenin plays important roles in mammary development and tumorigenesis through its functions in cell adhesion, signal transduction and regulation of cell-context-specific gene expression. Studies in mice have highlighted the critical role of $\beta$-catenin signaling for stem cell biology at multiple stages of mammary development. Deregulated $\beta$-catenin signaling disturbs stem and progenitor cell dynamics and induces mammary tumors in mice. Recent data showing deregulated $\beta$-catenin signaling in metaplastic and basal-type tumors suggest a similar link to reactivated developmental pathways and human breast cancer. The present review will discuss $\beta$-catenin as a central transducer of numerous signaling pathways and its role in mammary development and breast cancer.
\end{abstract}

\section{Introduction}

$\beta$-Catenin plays a significant role in the regulation of mammary development and tumorigenesis. At the plasma membrane, $\beta$-catenin aids cadherins in maintaining mammary epithelial integrity. In the nucleus, $\beta$-catenin regulates gene expression programs that are essential for mammary stem cell biology during mammary development. Loss of $\beta$-catenin from cell-cell adhesive junctions or elevation in the cytosol and nucleus can occur independently by numerous routes. Importantly, both events predispose the breast to cancer. In the present article we review pathways relevant to breast that feed into the $\beta$-catenin signaling node, the role of $\beta$-catenin signaling in normal mammary development, and the effects of deregulating $\beta$-catenin on breast cancer.

*Correspondence: cowinp01@nyumc.org

'Department of Cell Biology, MSB 621, New York University School of Medicine, 550 First Avenue, New York, NY 10016, USA

Full list of author information is available at the end of the article

\section{Upstream regulators}

Cadherin association

Breast epithelium is bilayered, comprising an inner luminal layer and a surrounding basal layer. In normal breast, the majority of $\beta$-catenin localizes to cell-cell adherens junctions through association with cadherins and only a minor portion is involved in signaling.

The importance of the cadherin/catenin complex for epithelial integrity and survival has been demonstrated by conditional deletion of E-cadherin. E-cadherin null cells undergo apoptosis but in the absence of p53 these cells survive and recapitulate many features of lobular breast cancer [1-3]. In humans, lobular breast cancer is associated with irreversible E-cadherin loss and transient changes in cadherin expression facilitate metastasis in many ductal breast cancers [4].

Although the consequences of $\beta$-catenin deletion have not been experimentally investigated, loss of cadherinbound $\beta$-catenin correlates significantly with poor outcome in breast cancer [5]. This loss can occur in three ways. Factors such as transforming growth factor beta (TGF $\beta$ ), and some Wnts, reduce catenin localization to adherens junctions by increasing Snail, Slug, Twist, Siah interacting protein (SIP) and WISP3 expression (for a review see [6]), which suppress E-cadherin transcription. Similarly, loss of $\mathrm{p} 120^{\mathrm{ctn}}$ - which prevents cadherin internalization - reduces membrane-bound $\beta$-catenin by destabilizing E-cadherin [7]. The major mechanism affecting catenin localization to the plasma membrane, however, involves phosphorylation. Many tyrosine kinases, notably epidermal growth factor receptor/ErbB1/Her1, Met, Abl, Src and Fer, directly regulate cadherin/catenin affinity for one another and are strongly implicated in breast cancer [8-14]. For instance, ErbB2/Her2/c-Neu mutation drives $30 \%$ of breast cancer, and increased $\beta$ catenin-ErbB2/Her2/c-Neu association has been documented in human infiltrating ductal adenocarcinoma and metastases $[15,16]$. Recent studies have also revealed that serine/threonine phosphorylation of the $\mathrm{N}$-terminal domain of $\beta$-catenin by GSK3 $\beta$ and CK1 kinases plays a significant role in compartmentalizing $\beta$-catenin [17]. A further mechanism of cadherin/catenin disruption involves the transmembrane mucin, MUC1, which competes with 
cadherins for catenin association [18,19]. MUC1 is overexpressed in $90 \%$ of breast carcinomas and parous MMTV-Muc1 mice develop mammary tumors [20].

\section{Canonical Wnt signaling}

While cadherin/catenin complexes are critical to mammary integrity, cytosolic and nuclear $\beta$-catenin serve a distinct role, transducing signals from multiple pathways into cell-context-specific gene expression patterns that are essential for mammary development. This role has been studied most intensively within the context of canonical Wnt signaling.

Wnts are secreted morphogens that provide positional information to neighboring cells through canonical and noncanonical signaling routes (for recent reviews, see $[21,22]$ - primary references and a detailed description of Wht pathways can be accessed online: http://www. stanford.edu/ rnusse/wntwindow.html). In brief, the canonical Wnt pathway operates by stabilizing cytosolic $\beta$ catenin (Figure 1). In the absence of Wnt signals, a multiprotein destruction complex - including the tumor suppressor adenomatous polyposis coli (APC) and Axin facilitates serine/threonine phosphorylation of the $\mathrm{N}$ terminal domain of $\beta$-catenin, which leads to its ubiquitination and proteosomal destruction. Wnt ligands prevent this sequence of events by binding to Frizzled receptors and signaling through the associated low-density lipoprotein-related proteins, LRP5/6. LRP signaling via Disheveled and Axin inhibits the destruction complex and thus induces cytoplasmic accumulation of $\beta$-catenin. This accumulation promotes $\beta$-catenin translocation to the nucleus, where it associates with T-cell factor/Lef DNA binding proteins, displaces transcriptional repressors, and recruits B-cell lymphoma-9/legless, pygopus homolog 2 (Pygo2) and other factors to induce cell-context-specific gene expression. Canonical Wnt signaling is highly conserved and, importantly, regulates stem cell dynamics in many tissues, including the breast [23].

\section{Other pathways regulating $\beta$-catenin signaling}

Although canonical Wnt signaling is the most wellknown path to $\beta$-catenin stabilization, numerous other signaling pathways - many of which are aberrant in breast cancer - also regulate $\beta$-catenin stability and transcriptional activity (Figure 2). For example, the prolyl isomerase Pin1 prevents association of $\beta$-catenin with APC, providing a major Wnt-independent stabilization mechanism [24]. Akt and ILK also stabilize $\beta$-catenin by inhibiting GSK3 $\beta$ activity. Importantly, the tumor suppressor phosphatase and tensin homolog (PTEN) inhibits both pathways $[25,26]$. Additionally, members of the p53-DNA damage pathway, Siah-1 (RING domain protein; transcriptional target of p53) and Ebi (F box protein) interact with APC to form an alternative destruction complex that recognizes and destroys $\beta$ catenin regardless of its phosphorylation status [27-29]. The p53 homolog, $\Delta$ Np63, was shown to be a target of p53-dependent destruction. During cancer, loss of p53 permits the aberrant interaction of $\triangle \mathrm{Np} 63$ with protein phosphatase (PP2A), which inhibits GSK3 $\beta$ leading to $\beta$ catenin stabilization [30]. Finally, critical kinases of the NF- $\kappa B$ signaling pathway (IKB kinase (IKK) $\alpha$ and IKK $\beta$ ) differentially regulate $\beta$-catenin transcription as well as activity [31]. IKK $\alpha$ phosphorylation increases stability and transcriptional activity of $\beta$-catenin, while phosphorylation by IKK $\beta$ decreases both [31]. In certain cell contexts, Wnts stimulate alternative effectors termed noncanonical pathways that can antagonize the $\beta$-catenin pathway (Figure 1). A web of regulatory pathways thus converges on cytosolic $\beta$-catenin and becomes transduced into a series of thresholds that exquisitely regulate the timely development and cyclical remodeling of the mammary gland. (See Table 1 for a summary of the phenotypes of transgenic and knockout mice used to study Wnt signaling in mammary development and cancer.)

\section{$\boldsymbol{\beta}$-catenin signaling and mammary stem cells}

In many epithelia, including breast, Wnt pathway activity is critical for stem cell self-renewal and multipotency [23]. $\beta$-Catenin signaling exerts powerful effects on mammary stem cells and progenitor cells. In mice, mammary stem cells reside among differentiated myoepithelial cells of the basal layer and alveolar progenitors are scattered among the differentiated cells of the luminal layer $[32,33]$. Recent studies have shown that Lrp5 is expressed in the basal epithelium and cells with high expression have a 200 -fold greater ability to regenerate a mammary tree when transplanted into cleared mammary fatpads. Conversely, Lrp5 $5^{-1-}$ cells lack this capability and show senescence in culture, demonstrating that canonical Wnt signaling is a critical for normal mammary stem cell maintenance [34]. Supporting this concept, exogenous Wnt 3A protects mammary stem cells from senescence and the loss of multipotency associated with long-term culture. Furthermore, MECS derived from mice where Wnt signaling is mildly derepressed outcompete wild-type MECS in mammary reconstitution assays [23]. The diverse roles of $\beta$-catenin signaling during mammary development, which we will now review, may thus be understood in a unified way when viewed through the lens of the highly conserved role of canonical Wnt signaling in regulating stem cell dynamics.

\section{Wnt/ $\beta$-catenin signaling during embryonic mammary development}

Wnt signaling is essential for specification and morphogenesis of the mammary gland [35]. Canonical Wnt signaling reporters define the mammary lines and later 


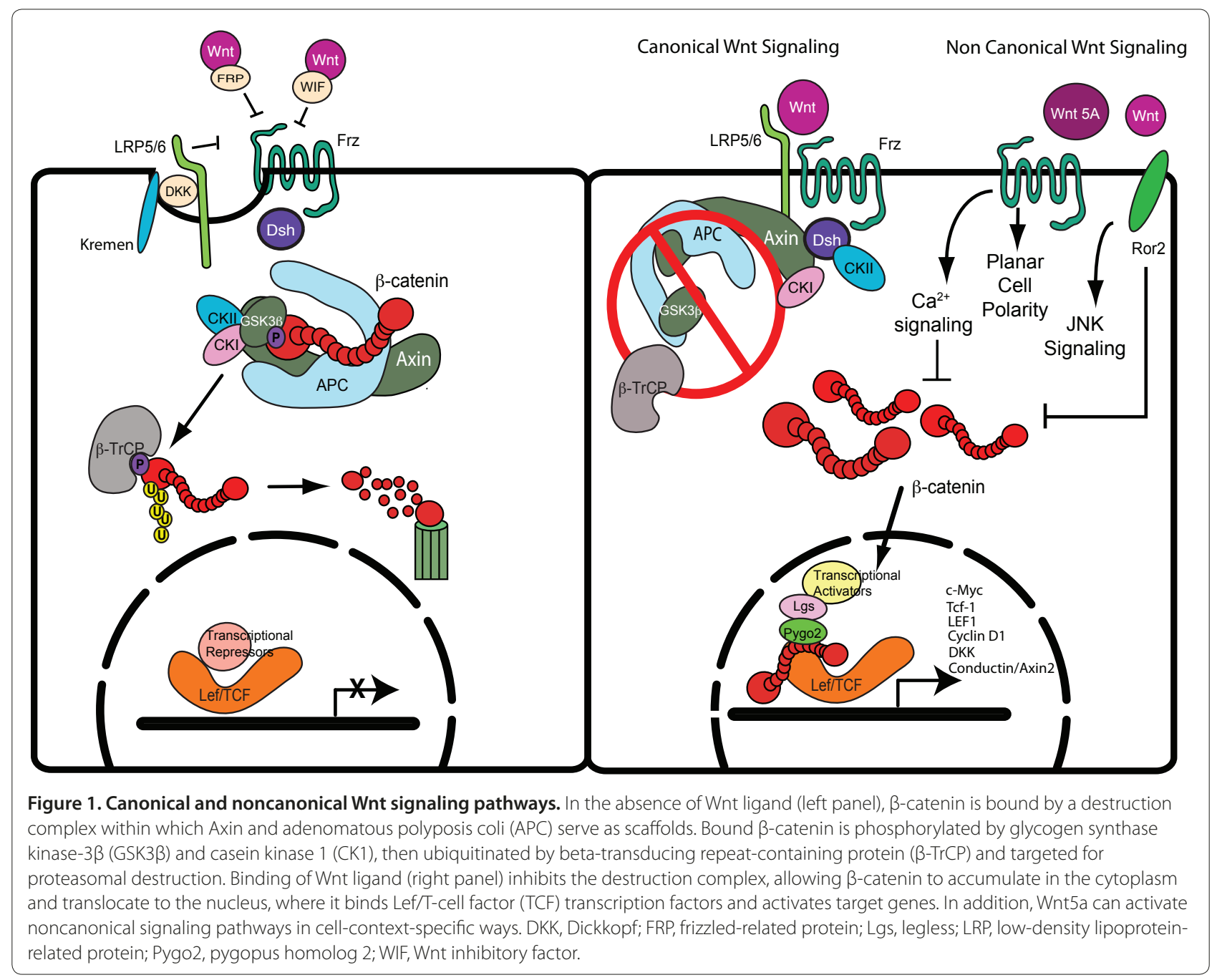

become restricted to cells forming placodes [36]. The functional importance of Wnt signaling is demonstrated by experiments showing that Dkk1 suppresses early canonical Wnt signaling, subsequent Wnt10b induction along the mammary line and all placodal development [36]. Targeting other positive acting elements of the Wnt pathway, such as Lrp6, Lrp5, Lef1 and Pygo2, also results in placodal impairments, ranging from loss to reduced size and degeneration, while stimulating $\beta$-catenin signaling produces the converse effect - acceleration, expansion and induction of placodes and placodal markers (Wnt10b and T-box transcription factor-3) [37-40]. Candidate activators of early $\beta$-catenin signaling include Wnt3, Wnt6 and Wnt10b, which are expressed diffusely throughout the ectoderm as well as a genetic hierarchy of factors, including ventral bone morphogenetic protein-4, dorsal T-box transcription factor-3, neuregulin-3 and somitic Fgf10, which function upstream to define the dorsal-ventral position of Wnt10b and Lef1 induction along the mammary line [35,41-48]. While these upstream factors are body-site specific, Wnt/B-catenin signaling is required universally by all mammary placodes - and indeed by all ectodermal appendages [36]. Downstream targets remain obscure but probably include ectodysplasin-A, which promotes placodal cell fate along the mammary line when overexpressed [49].

Canonical Wnt signaling is also essential for mammary morphogenesis when placodes invaginate to form flaskshaped buds. While recombinant Wnt3a accelerates this process, placodes from Lef1 $1^{-/-}$mice remain elevated and degenerate $[36,37,50]$. Bud invagination is dependent upon mammary mesenchyme specification, which is governed by parathyroid hormone-related peptide (PTHrP). Significantly, mesenchymal expression of canonical Wnt reporters, Lef1 and several target genes is dependent on PTHrP [51-56]. Microarray studies have begun to identify downstream effectors, and $\beta$-catenin target genes appear to represent an important module of the PTHrP-induced mammary mesenchyme specification process [57]. Ectodermal $\beta$-catenin signaling is also 


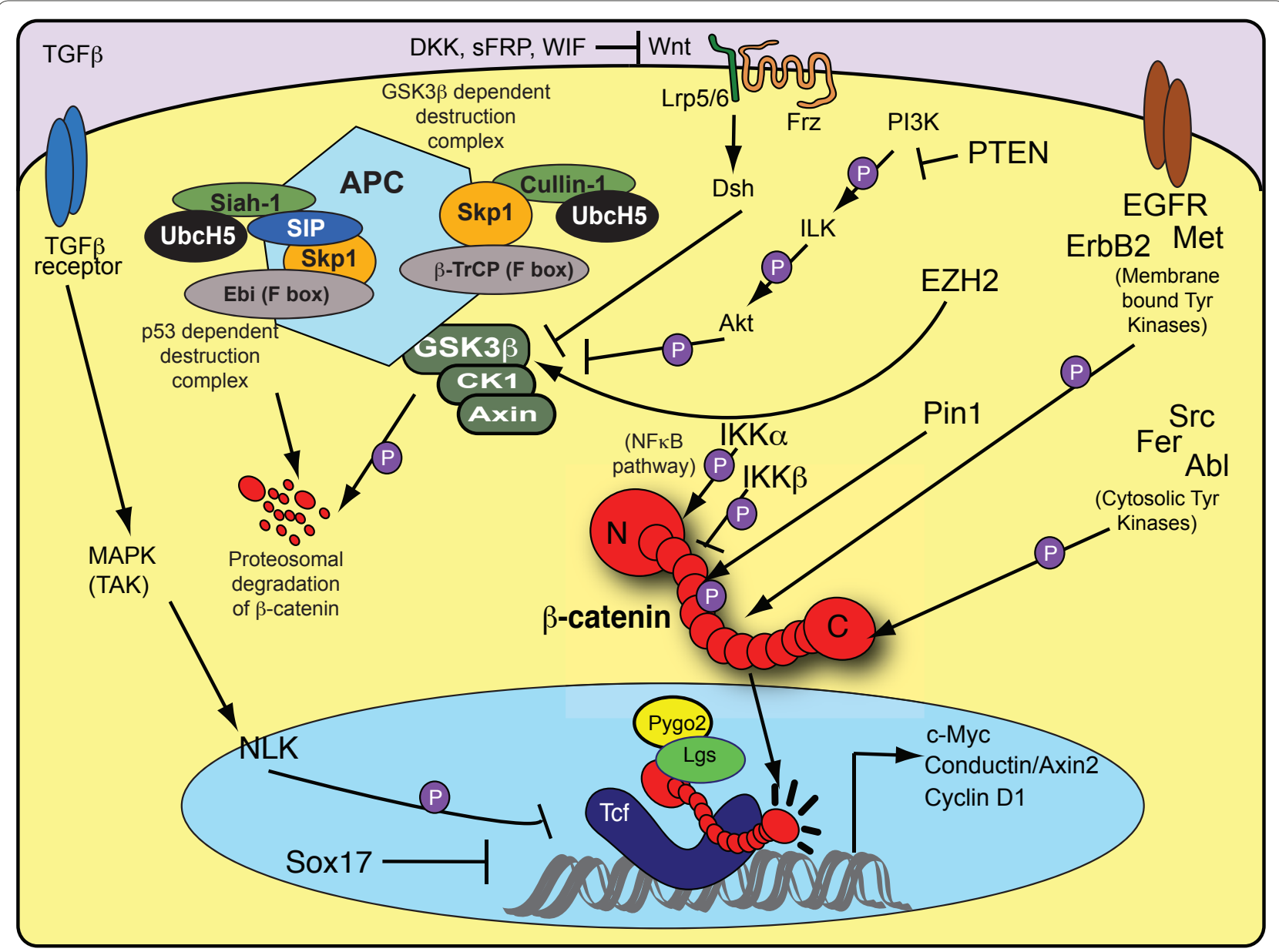

Figure 2. $\beta$-Catenin is at the hub of multiple signaling pathways. Many signaling pathways regulate the stability or binding interactions of $\beta$-catenin. In the Wnt pathway, glycogen synthase kinase-3ß (GSK3 3 ) and casein kinase 1 (CK1) phosphorylate the N-terminal degron sequence of $\beta$-catenin to facilitate its destruction. The phosphatidylinositol-3-kinase (PI3K) and phosphatase and tensin homolog (PTEN) pathways also impinge upon $\beta$-catenin phosphorylation by regulating GSK3 $\beta$ activity. In addition, p53 induces the degradation of $\beta$-catenin through protein interactions involving Seven in absentia homolog 1 (Siah1), Siah interacting protein (SIP) and EBV-induced G-protein coupled receptor (Ebi), resulting in ubiquitination and degradation of $\beta$-catenin. Pin 1 binds to $\beta$-catenin phosphorylated on S246P to prevent its association with adenomatous polyposis coli (APC). In the NF-KB pathway, IKB kinase (IKK)a and IKK $\beta$ phosphorylate $\beta$-catenin throughout the protein to activate and inhibit transcription, respectively, although the N-terminus is essential for IKKa regulation. Some proteins, such as those within the transforming growth factor beta (TGF $\beta$ ) pathway and Sox17, regulate $\beta$-catenin in the nucleus by modulating its interaction with transcriptional co-activators Tcf/Lef. Other proteins, like enhancer of zeste homolog 2 ( $\mathrm{EZH} 2$ ), interact with $\beta$-catenin to promote its translocation into the nucleus. A number of tyrosine kinases phosphorylate (both membrane bound and cytosolic) $\beta$-catenin to prevent its binding to the cadherin complex at the cell membrane. Src, epidermal growth factor receptor (EGFR), and erythroblastic leukemia viral oncogene-2 (ErbB2) have been shown or implicated to phosphorylate $\beta$-catenin on Y654, while Abelson tyrosine kinase (Abl) phosphorylates Y489. $\beta$-TrCP, beta-transducing repeat-containing protein; DKK, Dickkopf; Lgs, legless; LRP, low-density lipoprotein-related protein; MAPK, mitogen-activated protein kinase; NLK, Nemo-like kinase; Pygo2, pygopus homolog 2; sFRP, secreted frizzled-related protein; WIF, Wnt inhibitory factor.

important within a population of cells at the sprout tip that express Pygo2, a nuclear partner of $\beta$-catenin. Sprout downgrowth and branching are impaired in both Pygo $2^{-/-}$mice and Lrp6 $6^{-/-}$mice $[38,39]$.

\section{$\beta$-catenin signaling during pubertal mammary development}

Hormones temporally regulate postnatal development of the mammary gland, but their actions are relayed spatially by local paracrine factors. During puberty, estrogen, growth hormone and local IGF stimulate cell proliferation within terminal end buds to produce ductal extension. No direct connection has been established as yet between estrogen and canonical Wnt signaling. Several Wnts peak in expression during puberty, however, and Wnt5a and Wnt7b mRNAs are particularly enriched in terminal end buds and Wnt2 in the surrounding stroma [58-62]. Most reporters of canonical Wnt 
Table 1. Mouse models used to study canonical Wnt signaling in mammary development and cancer

\begin{tabular}{|c|c|c|c|}
\hline Mouse model & Structural modification & Mammary phenotype & References \\
\hline \multirow[t]{3}{*}{ MMTV- $\Delta$ N89- $\beta$-catenin } & Stabilizing deletion of first 89 amino acids of $\beta$-catenin & Expansion K18+CD29hi 49flo & {$[67,75]$} \\
\hline & Luminal expression & Precocious alveologenesis & \\
\hline & & Adenocarcinoma & \\
\hline \multirow[t]{2}{*}{ MMTV- $\triangle N 90-\beta$-catenin } & Stabilizing deletion of first 90 amino acids of $\beta$-catenin & Hyperplasia & {$[90]$} \\
\hline & Luminal expression & Adenocarcinoma & \\
\hline Catnb+/lox(ex3);WAP-Cre & $\begin{array}{l}\text { Stabilizing deletion of Exon } 3 \text { (codons } 5 \text { to 80) of } \\
\beta \text {-catenin }\end{array}$ & Squamous metaplasia & [93] \\
\hline Catnb+/lox(ex3);MMTV-Cre & Luminal expression & & \\
\hline \multirow[t]{2}{*}{ 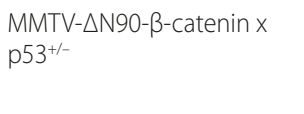 } & $\begin{array}{l}\text { Stabilizing deletion of } \beta \text {-catenin on a p } 53 \text { heterozygous } \\
\text { background }\end{array}$ & Adenocarcinomas & {$[175]$} \\
\hline & Luminal expression & Metastases & \\
\hline \multirow[t]{3}{*}{ K5- $\triangle N 57-\beta$-catenin } & Stabilizing deletion of first 57 amino acids of $\beta$-catenin & Precocious development during pregnancy & {$[38,74]$} \\
\hline & Basal expression & Hyperbranching & \\
\hline & & Multiparous mice develop invasive basal-type carcinoma & \\
\hline \multirow[t]{3}{*}{ MMTV-Wnt1 } & Wnt1 expression in luminal epithelia & Expansion of $\mathrm{K}_{1} 4^{+}, \mathrm{cd} 24^{+}, \mathrm{cd} 29 / 49 \mathrm{fhi}^{\text {hi }}$ basal stem cells & {$[33,67,84,85]$} \\
\hline & & Hyperbranching & \\
\hline & & Adenocarcinoma & \\
\hline \multirow[t]{3}{*}{ MMTV-Wnt10b } & Expression of long isoform of Wnt10b in luminal epithelia & Precocious alveologenesis & {$[61]$} \\
\hline & & Hyperbranching & \\
\hline & & Adenocarcinoma & \\
\hline MMTV-Lrp6 & Expression of Lrp6 in luminal epithelia & Hyperplasia no tumors & {$[88]$} \\
\hline \multirow[t]{2}{*}{$\mathrm{Apc}^{\mathrm{Min} /+}$} & Truncating mutation of APC at codon 850 & Focal alveolar hyperplasias & [178] \\
\hline & & $\begin{array}{l}\text { Mammary carcinomas ( } 7 \text { to } 20 \% \text { depending on strain } \\
\text { background) }\end{array}$ & \\
\hline \multirow[t]{2}{*}{$\mathrm{Apc}^{+1 / 1572}$} & Truncating mutation of APC at codon 1572 & Multifocal mammary adenocarcinomas (85.7\%) & [95] \\
\hline & & Pulmonary metastases & \\
\hline \multirow[t]{2}{*}{ K14-cre-Apc ${ }^{580 /+}$} & Truncating mutation of APC at codon 580 & Mammary adenocarcinomas & [94] \\
\hline & Basal expression & & \\
\hline \multirow[t]{2}{*}{ BLG-Cre; Apc ${ }^{580 / / 5805}$} & Truncating mutation of APC at codon 580 & Delayed ductal morphogenesis & [179] \\
\hline & Luminal expression & Metaplasia & \\
\hline $\begin{array}{l}\text { MMTV-rtTA;TRE2-myc- } \\
\text { tagged Axin-(IRES) GFP }\end{array}$ & Doxycycline-inducible Axin in luminal epithelia & Loss of alveologenesis & [76] \\
\hline WAP- $\beta$-engrailed & $\beta$-engrailed expressed luminally & Failure to maintain alveoli & [77] \\
\hline MMTV- $\beta$-engrailed & & Lactation defect & \\
\hline \multirow[t]{4}{*}{$\operatorname{Lrp5}^{-/-}$} & Loss of Lrp5 & Loss of placodes & {$[34,39]$} \\
\hline & & Mild ductal hypoplasia & \\
\hline & & Reduced regenerative capacity & \\
\hline & & Resistant to Wnt-induced tumorigenesis & \\
\hline \multirow[t]{2}{*}{$\operatorname{Lrp6}^{-/-}$} & Loss of Lrp6 & Impaired sprouting, placode and fat pad development & {$[40]$} \\
\hline & & Decreased number of TEBs in heterozygotes & \\
\hline Wnt4 ${ }^{-/}$ & Loss of Wnt4 & Delayed side-branching & [69] \\
\hline Wnt5 $a^{-/-}$ & Loss of Wnt5a & Accelerated ductal morphogenesis & [64] \\
\hline K5-rtTA/tetO-DKK1 & Ectopic expression of Dkk1 & Loss of mammary line and all placodal development & [36] \\
\hline \multirow[t]{2}{*}{ K14-Cre/Pygo2 flox } & Loss of Pygo 2 in mammary epithelium & Loss and small placodes & {$[38]$} \\
\hline & & Progressive loss of progenitor cell population & \\
\hline Pin $1^{-1-}$ & Loss of Pin 1 & $\begin{array}{l}\text { Severe decrease in ductal and alveolar development } \\
\text { during pregnancy }\end{array}$ & {$[80]$} \\
\hline \multirow[t]{3}{*}{ RANK $^{-/-}$} & Loss of RANK receptor & Loss of alveologenesis & {$[78,79]$} \\
\hline & & Failure to lactate & \\
\hline & & Impaired side-branching in transplanted null outgrowths & \\
\hline \multirow[t]{2}{*}{ Lef1 $^{-1-}$} & Loss of Lef1 & Impaired placodes & {$[37]$} \\
\hline & & Impaired bud morphogenesis & \\
\hline $\mathrm{Rspo}^{-1-}$ & Loss of Rspo1 & Defective side branching & [73] \\
\hline
\end{tabular}

APC, adenomatous polyposis coli; DKK, Dickkopf; GFP, green fluorescence protein; LRP, low-density lipoprotein-related protein; MMTV, mouse mammary tumor virus; Pygo2, pygopus homolog 2; RANK, receptor activator of NF-KB; TEB, terminal end bud; WAP, whey acidic protein. 
signaling remain silent, but weak Conductin-lacZ expression is seen in basal cells and stroma surrounding the terminal end buds [23]. Conductin/Axin2 is an endogenous target gene that is faithfully expressed in response to canonical Wnt signaling and serves as a negative feedback loop to downregulate the pathway [63]. These observations indicate that $\beta$-catenin signaling occurs at low levels. Genetically reducing canonical Wnt receptors produces mild effects: Lrp5 $5^{-/-}$mutants and Lrp6 $^{+/-}$mutants show fewer terminal end buds, Lrp5 $5^{-/-}$ mutants show delayed ductal extension, and $\operatorname{Lrp6}^{+/-}$ mutants show reduced ductal branching. Compound Lrp6 $6^{+-} ;$Lrp5 $^{-/-}$mutants show no ductal outgrowth, however, demonstrating a requirement for canonical Wnt pathway activity $[34,39,40]$.

Current evidence suggests that noncanonical Wnt antagonism of canonical Wnt pathways is important. For example, loss of Wnt5a, which stimulates noncanonical signaling pathways during other polarized morphogenic events, increases cytoplasmic and nuclear $\beta$-catenin and accelerates ductal outgrowth [64]. Importantly, Wnt5a is an essential mediator of TGF $\beta$, suggesting that low thresholds of $\beta$-catenin signaling are maintained during pubertal ductal morphogenesis through TGF $\beta$ and Wnt5a antagonism.

\section{Links between progesterone and $\beta$-catenin signaling during ductal maturation}

A significant body of data shows that progesterone not only promotes Wnt expression but also induces competence to respond to $\beta$-catenin signaling within specific mammary progenitors. Progesterone receptor (PR) is expressed in most luminal cells in juveniles but becomes downregulated and interspersed with PR-negative cells in adults. This patterning event requires PR and generates PR-negative progenitors that produce side branches and alveoli during pregnancy [65]. Expression of a stabilized form of $\beta$-catenin lacking $\mathrm{N}$-terminal phosphorylation degron sequences (MMTV- $\Delta$ N89 $\beta$-catenin) uniformly within the luminal epithelium induces signaling within this progenitor population, resulting in precocious development at regular intervals along ducts [66,67]. In the absence of PR, however, $\triangle N 89 \beta$ is only able to produce this effect at ductal tips $[66,67]$. This observation suggests that PR specifies and spatially patterns alveolar progenitors by inducing a factor that is essential for $\beta$ catenin's nuclear entry or transcriptional activity and thus renders cells poised to receive a $\beta$-catenin signal $[66,67]$. Progesterone also induces several paracrine factors - for example, Wnt4 and receptor activator of NF- $\mathrm{kB}$ ligand (RANKL) - in PR-positive luminal cells that signal to their neighbors [68-70]. A recent study has highlighted the importance of these paracrine effectors during estrus, showing that their expression correlated with $\beta$-catenin target gene expression in both luminal and basal cells and with increased stem cell activity [71].

\section{Canonical Wnt signaling during pregnancy}

Wnts and RANKL also function downstream of progesterone to stimulate side-branching and alveolar development during pregnancy [68-70]. Wnt4, Wnt5b and Wnt6 peak sequentially - and deletion of the earliest, Wnt4, delays side-branching, whereas ectopic Wnt4 expression promotes side-branching $[58,69,72]$. The gene for Rspo1 - which encodes an alternative (non-Wnt) ligand for Lrp6, and activates $\beta$-catenin signaling - is expressed during early pregnancy, and its deletion similarly affects side-branching [73]. Canonical Wnt signaling exerts dose-dependent effects on ductal branching: Conductin ${ }^{\text {lacz/+ }}$ mice show no phenotype but further pathway derepression in Conductin ${ }^{\text {lacz/lacz }}$ mice results in mild hyperbranching and strong activation in $\mathrm{K} 5-\Delta \mathrm{N} 57 \beta-$ catenin or MMTV-Wnt1 mice produces dramatic hyperbranching and gross ductal distortion [23,67,74,75]. Importantly, canonical Wnt signaling in Conductin ${ }^{\mathrm{LacZ} /}$ LacZ mice and in MMTV-Wnt1;Conductin ${ }^{\mathrm{LacZ} /+}$ mice is detected in basal cells $[67,69]$. This observation suggests that Wnts expressed by luminal cells regulate ductal morphogenesis in a paracrine manner by inducing a canonical Wnt signaling response in basal cells $[67,69]$.

In sharp contrast, a series of studies have shown that activation of $\beta$-signaling within specific hormone receptor-negative luminal cell populations promotes and is required for alveologenesis. Expression of MMTV$\Delta \mathrm{N} 89 \beta$-catenin within luminal cells induces precocious alveologenesis in virgin mice $[67,75]$. $\beta$-Catenin signaling reporters are transiently expressed during normal alveologenesis, and inhibiting endogenous $\beta$-catenin signaling within luminal cells by expressing a negative regulator (Axin) or a dominant negative form of $\beta$ catenin ( $\beta$-engrailed) prevents alveologenesis and caused alveolar degeneration $[36,50,76,77]$. Together, these studies establish that luminal $\beta$-catenin signaling is essential for alveologenesis and survival.

The upstream activator remains to be defined but is unlikely to involve Wnts since luminal cells express no obvious Wnt receptor and alveologenesis proceeds in the absence of Lrp5 [34]. Intriguingly, RANKL stabilizes $\beta$ catenin in other contexts and, like $\beta$-catenin, specifically promotes the proliferation of PR-negative cells $[78,79]$. RANKL $^{-/-}$mice and mice expressing Axin show similar impairment in alveologenesis [76,79]. Importantly, Pin1, which provides a Wnt-independent route to $\beta$-catenin stabilization, is critical for alveolar development during pregnancy $[24,80]$. Downstream targets of $\beta$-catenin signaling remain obscure. $\mathrm{C}-m y c$ and cyclin $\mathrm{D}_{1}$ are reduced and increased in mice where the pathway is suppressed and is increased, respectively [67,75-77]. 
Cyclin $\mathrm{D}_{1}$, however, is dispensable for the proliferative response to MMTV- $\Delta \mathrm{N} 89 \beta$-catenin, MMTV-Wnt1 and RANKL, and instead drives early and later postpartum waves of cell division $[79,81,82]$.

In summary, Wnts and RANKL promote stem cell amplification $[33,71]$ and branching $[58,69,72]$ by paracrine induction of $\beta$-catenin signaling in basal cells $[34,39,40,67,71]$. In contrast, $\beta$-catenin signaling in luminal progenitors is essential for alveologenesis and is probably induced by Wnt-independent mechanisms (for a model, see Figure 3) $[67,76,77]$.

\section{Deregulating $\boldsymbol{\beta}$-catenin signaling in mammary stem and progenitor cells induces cancer}

Just as regulation of stem cells is key to understanding the function of $\beta$-catenin signaling during embryonic and adult mammary development, its proto-oncogenic properties may be viewed as arising from unbridled stem and early progenitor expansion. More than 25 years ago, retroviral insertion resulting in Wnt1 activation was found to induce mammary tumors - and, subsequently, transgenic expression of Wnt1, Wnt3 and Wnt10b was shown to produce similar effects $[61,83,84]$. A series of studies have revealed that exposure of glands to excessive Wnt1 or activated $\Delta N 89 \beta$-catenin leads to progressive accumulation of cells displaying stem and progenitor marker profiles and enhanced colony-forming ability and bipotency in vitro [67,85-88]. Reporter studies indicate that Wnt1 activates $\beta$-catenin signaling in a paracrine manner, increasing basally located multipotent stem cells at the expense of differentiated myoepithelial cells [67]. The pivotal role of a canonical Wnt pathway versus a noncanonical Wnt pathway in this process has been demonstrated by the fact that $\mathrm{Lrp}^{-/-}$mice are highly resistant to Wnt1 tumor development and show significantly delayed tumor onset $[39,40]$. Collectively, these studies indicate that paracrine signals from MMTVexpressing luminal cells promote $\beta$-catenin signaling within a basal stem cell population and induce mixed lineage tumors. In keeping with this scenario, continuous Wnt1 expression is required for tumor maintenance [89].

Mice expressing activated $\beta$-catenin from the MMTV promoter also develop adenocarcinoma with $100 \%$ penetrance $[75,90]$. In this mouse model, however, reporter studies have shown that $\beta$-catenin signaling occurs within a distinct subset of luminal cells scattered along ducts with alveolar progenitor marker profiles and functional characteristics [67]. These studies show that deregulation of $\beta$-catenin signaling within luminal progenitor cells also produces tumors of mixed lineage [67,85-88]. Significantly, in humans, basal-type hormone receptor-negative breast cancer is thought to arise from luminal progenitors. Target genes include matrix metalloproteinases, cyclin $\mathrm{D}_{1}$ and c$m y c$, which are upregulated in both MMTV-Wnt1 and

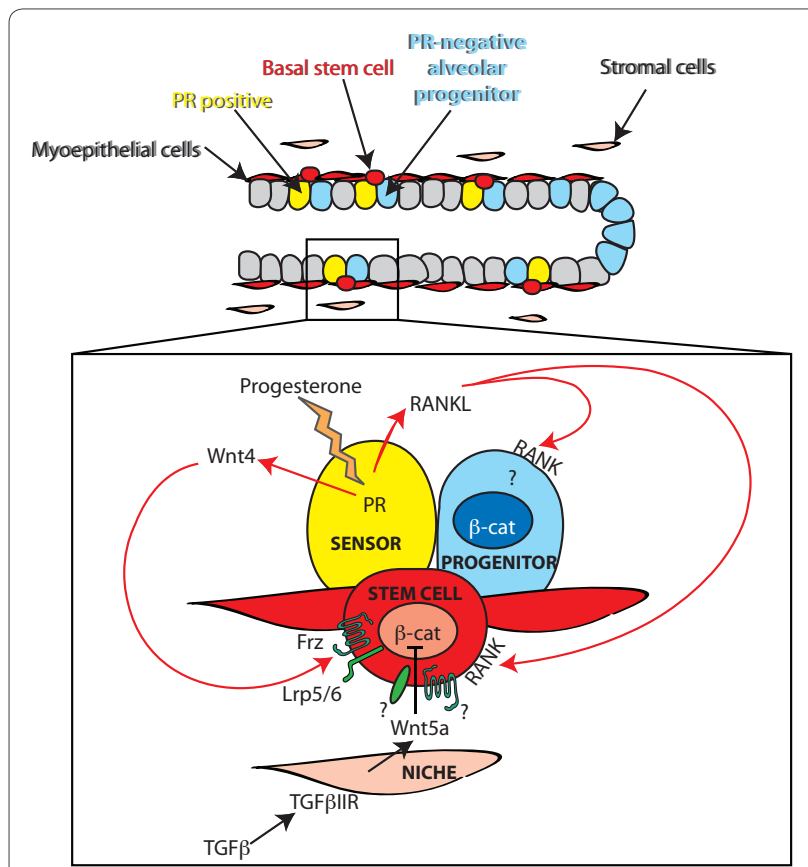

Figure 3. Hypothetical model for paracrine activation of $\beta$-catenin signaling in the mammary gland. Progesterone receptor (PR) induces Wnts and receptor activator of NF-KB ligand (RANKL). These paracrine factors bind to their respective receptors low-density lipoprotein-related protein (LRP) $5 / 6$ and RANK in basal cells. $\beta$-catenin signaling in this cell type induces stem cell amplification and branching. Transforming growth factor beta (TGF $\beta$ ) signaling within stromal cells restrains ductal morphogenesis by inducing Wnt5a. Wnt5a antagonizes canonical Wnt signaling, possibly via noncanonical Wnt pathways. $\beta$-Catenin signaling in luminal progenitors is essential for alveologenesis. As luminal cells lack Wnt receptors, however, it is likely that $\beta$-catenin signaling is induced in this cell-type by Wnt-independent mechanisms.

MMTV- $\Delta$ N89 $\beta$-catenin glands. Cyclin $D_{1}$, however, is dispensable for tumor initiation [81,91]. In fact, MMTV$\Delta N 89 \beta$-catenin mice lacking cyclin $\mathrm{D}_{1}$ present accelerated tumor onset and higher tumor burden [91]. Lastly, canonical Wnt pathway activity has been implicated in mediating radiation resistance in mammary Sca1-positive progenitors by inducing Survivin expression [92].

The response to $\beta$-catenin signaling is highly context dependent. K5- $\Delta \mathrm{N} 57 \beta$-catenin mice develop basal preneoplasia and invasive ductal carcinomas, while activation of $\beta$-catenin by MMTV-cre-targeted or whey acidic protein-cre-targeted exon 3 deletion shows squamous metaplasia [74,93]. Likewise, a mutant APC generated mammary adenocarcinomas when expressed in the basal layer but induced squamous metaplasia when expressed in differentiating luminal cells [94]. APC mutants have also revealed tissue-specific dose responses. The $\mathrm{APC}^{\mathrm{Min} /+}$ mutation, which results in high levels of $\beta$-catenin, predominantly causes intestinal polyposis, while APC mutants that generate intermediate levels of $\beta$-catenin 
preferentially induce mammary tumors [95]. The strain background influences the tumorigenic properties of $\mathrm{APC}^{\mathrm{Min} /+}$ and genetic studies have begun to identify tissue-specific modifier loci [96].

Tumor microenvironmental factors also exert powerful effects on the tumor phenotype. For example, inhibiting TGF $\beta$ signaling in stromal cells by expression of a dominant negative receptor (metallothionine inducible dominant-negative TGF $\beta$ receptor II transgene) increases $\beta$-catenin signaling within the epithelium of MMTVNeu-induced and MMTV-PyVmT-induced tumors. This is accompanied by a remarkable change in tumor phenotype from one that is principally luminal to one with mixed luminal and basal cell types [97]. Similar effects are produced by eliminating the TGF $\beta$ target gene and the paracrine effector, Wnt5a [97]. The tumor microenvironment is in turn influenced by Wnt1, which impairs laminin deposition, disrupts cell polarity, promotes stromal hyperplasia and induces hedgehog signaling activity, suggesting important connections between these pathways in tumor onset $[67,98]$.

\section{$\beta$-catenin in human breast cancer}

Studies in mice strongly suggest that deregulated $\beta$ catenin signaling increases the breast cancer risk by inducing stem and early progenitor cell accumulation $[67,85]$. Consistent with this hypothesis, a gene expression signature derived from MMTV-Wnt1 tumorinitiating cells was found to have prognostic value in determining poor outcome associated with specific breast cancer types, including basal-like and hormone receptor-negative cancers [99]. Genes of the canonical Wnt pathway featured prominently in a breast-to-lung metastasis signature that was significantly correlated with poor prognosis and reduced overall survival. Finally, Wnt1 tumors share transcriptional patterns with $\mathrm{BRCA}^{+/-}$tumors and human basaloid tumors, and several studies have linked Lrp6 and nuclear $\beta$-catenin with triple-negative breast cancer [40,100-103].

Stabilizing mutations in the $\beta$-catenin $\mathrm{N}$-terminal sequence found in other human cancers are uncommon in breast cancer and, until recently, were only reported in benign fibromas $[104,105]$. Such mutations have now been found in $25 \%$ of metaplastic breast cancers [106]. In contrast to the rarity of mutation, $\beta$-catenin expression and/or localization are often abnormal in human breast cancer [5,24,106-109]. Increased cytoplasmic and nuclear $\beta$-catenin levels have been documented in $40 \%$ of primary breast cancers and correlated with poor prognosis and worse patient survival [24,107,109-114]. These observations suggest that upstream elements of Wnt and/ or other pathways that stabilize $\beta$-catenin catenin are deregulated in breast cancer. Indeed, a significant number of breast tumors develop in an environment of unopposed Wnt ligand activity [112,115-120]. Inactivation of genes encoding secreted Wnt pathway inhibitors, such as secreted frizzled-related protein (sFRP), Wnt inhibitory factor and DKK, occurs frequently in breast cancer. sFRP1 levels are diminished in infiltrating (or invasive) ductal carcinoma, and gain and loss of sFRP1 suppresses and promotes invasiveness of breast cancer, respectively $[112,116,117,119,120]$. sFRP1, sFRP5, Wnt inhibitory factor-1 and DKK3 are transcriptionally silenced by promoter methylation in 27 to $100 \%$ of breast cancers $[118,121-125]$. Silencing of sFRP1, in particular, is a prognostic indicator of poor overall survival. One study found DKK1 to be preferentially expressed in hormone receptor-negative cancers; as DKK is a Wht target gene, however, this elevation may actually indicate augmented pathway activity [126].

There is also mounting evidence for excess Wnt ligand production, aberrant receptor activation and loss of noncanonical Wnt antagonism in human breast cancer. Wnt2, Wnt4 and Wnt10b mRNA upregulation has been reported [112,127-134]. Wnt5a, which negatively regulates $\beta$-catenin activity during mammary development, is lost in a proportion of human infiltrating (or invasive) ductal carcinoma and is a powerful predictor of recurrence [135]. FRZ1 and FRZ2 upregulation occurs and a splicing mutation in LRP5 that induced $\beta$-catenin activity was found in $85 \%$ of tumors [136,137]. Two studies have reported increased LRP6 expression in human breast cancer, particularly in triple-negative basal-like subtypes $[40,102]$. One study showed that Mesd, an inhibitor of Lrp5/6 folding, suppressed growth of MMTV-Wnt1 tumors despite the presence of excess ligand and without adverse effects on normal Wnt-driven processes, suggesting that Lrp6 may have potential as a therapeutic target [102].

Disheveled, which promotes $\beta$-catenin signaling, is upregulated in up to $50 \%$ of primary breast cancers $[113,138]$. Moreover, although mutations in negative regulatory components such as APC and Axin, are rare, loss of heterozygosity, downregulation or epigenetic silencing of these genes occurs in up to $70 \%$ of breast tumor cell lines and cancers [105,108,109,114,139-152]. Nuclear transcriptional cofactors such as Pygo2 show upregulated expression in a number of human invasive ductal cancers and are required for anchorage-independent growth in human breast cancer cell lines [153]. EZH2, which promotes nuclear translocation of $\beta$-catenin and transcriptional activity, induces ductal hyperplasia and involution defects in MMTV-EZH2 mice and is highly expressed in human breast carcinomas [154].

A number of Wnt target genes are implicated in breast cancer. Genes encoding c- $m y c$ and cyclin $\mathrm{D}_{1}$ are amplified and upregulated in $40 \%$ of human breast cancers [107,155-158]. Cyclin $D_{1}$ is dispensable for Wnt or 
$\beta$-catenin murine tumorigenesis; however, Myc activates Wnt signaling by suppressing DKK and sFRP1, providing positive feedback to sustain the cancerous state $[81,91$, 159]. Other relevant $\beta$-catenin targets include WISP1, Slug, Twist, Sox17, and Limb Heart Bud [100,160-163]. Sox17, a transcriptional antagonist of canonical Wnt signaling, is epigenetically silenced in $74.3 \%$ of breast tumors [162]. Limb Heart Bud, an important embryonic patterning gene, is upregulated in MMTV-Wnt tumors and many human breast cancers. This gene is highly expressed in $50 \%$ of basal breast cancers, again suggesting that this breast cancer subtype may involve reactivation of dormant developmental signaling pathways [163].

An increasing body of evidence suggests that stabilization of $\beta$-catenin by Wnt-independent routes, such as Pin1, p53, PTEN/Akt and NF-kB pathways, plays a significant role in breast cancer. For example, Pin1 upregulation correlates with increasing cancer grade (25\% in ductal carcinoma in situ, $71.4 \%$ in grade II tumors, and $89.5 \%$ in grade III tumors) [164], and is associated with increased expression of $\beta$-catenin in breast tumors [24]. Components of the NF- $\mathrm{B}$ B pathway, which can differentially regulate $\beta$-catenin, are also activated in estrogen receptor-negative/ErbB2-positive breast cancers (86\%) [165].

Loss of PTEN and p53 tumor suppressors has also been linked to induction of $\beta$-catenin in breast cancer. Germline PTEN mutations are common in patients with Cowden's syndrome, showing a lifetime risk of 25 to $50 \%$ for developing breast cancer, and sporadic PTEN loss correlates with invasive breast carcinomas $(48 \%, n=151)$ $[166,167]$. Significantly, overexpression of PTEN partially inhibits Wnt-induced tumorigenesis; conversely, loss of PTEN and activation of Akt caused an expansion of normal and malignant breast stem cells via activation of $\beta$-catenin $[26,167,168]$. These data suggest that the ability of PTEN to act as a tumor suppressor is mediated partly through the Wnt pathway. In addition to PTEN, inhibitor of differentiation binding-1, Slit-2 and melanoma differentiation association gene-7 proteins all regulate $\beta$ catenin in breast cancer cells through the phosphatidylinositol-3-kinase pathway [169-171].

Mutations in the p53 gene cause the heritable disease Li-Fraumeni syndrome, which is characterized by an 18-fold enhancement in susceptibility to breast cancer. p53 mutation occurs in 50\% of all human cancers and in $20 \%$ of sporadic breast cancer (for a review see [172]). $\beta$ Catenin is downregulated by $\mathrm{p} 53$ and is also degraded through a p53-dependent mechanism, which included Siah1, SIP and Ebi [27-29]. Adding to the complexity, Siah1 has splice variants that differentially affect $\beta$ catenin in breast cancer cells $[173,174]$. MMTV- $\Delta N \beta-$ catenin tumors induced in $\mathrm{p} 53^{+/-}$mice are more malignant and metastatic than those in $\mathrm{p} 53^{+/+}$mice [175].
Likewise, patients with breast cancers displaying high levels of $\beta$-catenin and p53 had worse survival [176]. Additionally, p63 was shown to be highly upregulated in metaplastic breast carcinomas $(86.7 \%, n=15)$ [177].

\section{Conclusions}

Evidence from murine models show that deregulated $\beta$ catenin signaling in basal stem cells or luminal progenitors induces breast tumors. This event correlates with disturbances in the homeostatic balance between stem cell and early progenitor cell self-renewal and the production of differentiated progeny. There are numerous pathways, in addition to the canonical Wnt pathway, which regulate $\beta$-catenin. Mutations in $\beta$-catenin are rare but deregulated $\beta$-catenin signaling occurs frequently in human breast cancer and may be particularly relevant for basal-type and triple-negative subtypes, suggesting important links between reactivation of developmental pathways and this breast cancer subtype.

\section{Competing interests}

The authors declare that they have no competing interests.

\section{Abbreviations}

Abl, Abelson tyrosine kinase; APC, adenomatous polyposis coli; DKK, Dickkopf; EBI, EBV-induced G-protein coupled receptor 1; ErbB, erythroblastic leukemia viral oncogene; $E Z H 2$, enhancer of zeste homolog 2; FGF, fibroblast growth factor; GSK3 $\beta$, glycogen synthase kinase-3 $\beta$; IKK, IKB kinase; LRP, low-density lipoprotein-related protein; K5, keratin 5; MMTV, mouse mammary tumor virus; Muc1, mucin 1; NF, nuclear factor; PR, progesterone receptor; PTEN, phosphatase and tensin homolog; PTHrP, parathyroid hormone-related peptide; Pygo2, pygopus homolog 2; RANKL, receptor activator of NF-KB ligand; sFRP, secreted frizzled-related protein; $\mathrm{SIAH1}$, seven in absentia homolog 1; SIP, Siah interacting protein; TGF $\beta$, transforming growth factor beta; WISP, Wnt-inducible signaling pathway protein.

\section{Author details}

'Department of Cell Biology, MSB 621, New York University School of Medicine, 550 First Avenue, New York, NY 10016, USA. ${ }^{2}$ Department of Dermatology, New York University School of Medicine, 550 First Avenue, New York, NY 10016, USA.

\section{Acknowledgements}

The present work was supported by DOD-BC093088 and NIH-R21-CA129905. Al is supported by the Susan G. Komen Breast Cancer Research Foundation postdoctoral fellowship PDF0707333.

Published: 3 November 2010

\section{References}

1. Boussadia O, Kutsch S, Hierholzer A, Delmas V, Kemler R: E-cadherin is a survival factor for the lactating mouse mammary gland. Mech Dev 2002, 115:53-62.

2. Derksen PW, Liu X, Saridin F, van der Gulden H, Zevenhoven J, Evers B, van Beijnum JR, Griffioen AW, Vink J, Krimpenfort P, Peterse JL, Cardiff RD, Berns A, Jonkers J: Somatic inactivation of E-cadherin and p53 in mice leads to metastatic lobular mammary carcinoma through induction of anoikis resistance and angiogenesis. Cancer Cell 2006, 10:437-449.

3. Berx G, Cleton-Jansen AM, Nollet F, de Leeuw WJ, van de Vijver M, Cornelisse C, van Roy F: E-cadherin is a tumour/invasion suppressor gene mutated in human lobular breast cancers. EMBO J 1995, 14:6107-6115.

4. Nagi C, Guttman M, Jaffer S, Qiao R, Keren R, Triana A, Li M, Godbold J, Bleiweiss IJ, Hazan RB: N-cadherin expression in breast cancer: correlation with an aggressive histologic variant - invasive micropapillary carcinoma. Breast Cancer Res Treat 2005, 94:225-235. 
5. Dolled-Filhart M, McCabe A, Giltnane J, Cregger M, Camp RL, Rimm DL: Quantitative in situ analysis of beta-catenin expression in breast cancer shows decreased expression is associated with poor outcome. Cancer Res 2006, 66:5487-5494.

6. Foubert E, De Craene B, Berx G: Key signalling nodes in mammary gland development and cancer. The Snail1-Twist1 conspiracy in malignant breast cancer progression. Breast Cancer Res 2010, 12:206.

7. Kowalczyk AP, Reynolds AB: Protecting your tail: regulation of cadherin degradation by p120-catenin. Curr Opin Cell Biol 2004, 16:522-527.

8. Roura S, Miravet S, Piedra J, Garcia de Herreros A, Dunach M: Regulation of E-cadherin/catenin association by tyrosine phosphorylation. J Bio/ Chem 1999, 274:36734-36740.

9. Biscardi JS, Ishizawar RC, Silva CM, Parsons SJ: Tyrosine kinase signalling in breast cancer: epidermal growth factor receptor and c-Src interactions in breast cancer. Breast Cancer Res 2000, 2:203-210.

10. Shomori K, Ochiai A, Akimoto S, Ino Y, Shudo K, Ito H, Hirohashi S: Tyrosinephosphorylation of the 12th armadillo-repeat of beta-catenin is associated with cadherin dysfunction in human cancer. Int J Oncol 2009, 35:517-524

11. Srinivasan D, Plattner R: Activation of Abl tyrosine kinases promotes invasion of aggressive breast cancer cells. Cancer Res 2006, 66:5648-5655.

12. Rhee J, Buchan T, Zukerberg L, Lilien J, Balsamo J: Cables links Robo-bound Abl kinase to N-cadherin-bound beta-catenin to mediate Slit-induced modulation of adhesion and transcription. Nat Cell Biol 2007, 9:883-892.

13. Ponzo MG, Lesurf R, Petkiewicz S, O'Malley FP, Pinnaduwage $D$, Andrulis IL, Bull SB, Chughtai N, Zuo D, Souleimanova M, Germain D, Omeroglu A, Cardiff RD, Hallett M, Park M: Met induces mammary tumors with diverse histologies and is associated with poor outcome and human basal breast cancer. Proc Natl Acad Sci U S A 2009, 106:12903-12908.

14. Graveel CR, DeGroot JD, Su Y, Koeman J, Dykema K, Leung S, Snider J, Davies SR, Swiatek PJ, Cottingham S, Watson MA, Ellis MJ, Sigler RE, Furge KA, Vande Woude GF: Met induces diverse mammary carcinomas in mice and is associated with human basal breast cancer. Proc Natl Acad Sci U S A 2009, 106:12909-12914

15. Schroeder JA, Adriance MC, MCConnell EJ, Thompson MC, Pockaj B, Gendler $\mathrm{SJ}$ : ErbB-beta-catenin complexes are associated with human infiltrating ductal breast and murine mammary tumor virus (MMTV)-Wnt-1 and MMTV-c-Neu transgenic carcinomas. J Biol Chem 2002, 277:22692-22698.

16. Zhou BP, Hung MC: Dysregulation of cellular signaling by HER2/neu in breast cancer. Semin Oncol 2003, 30(5 Suppl 16):38-48.

17. Maher MT, Mo R, Flozak AS, Peled ON, Gottardi CJ: Beta-catenin phosphorylated at serine 45 is spatially uncoupled from beta-catenin phosphorylated in the GSK3 domain: implications for signaling. PLoS One 2010, 5:e10184.

18. Yamamoto M, Bharti A, Kufe D: Interaction of the DF3/MUC1 breast carcinoma-associated antigen and $\beta$-catenin in cell adhesion. J Bio/ Chem 1997, 272:12492-12494.

19. Kondo K, Kohno N, Yokoyama A, Hiwada K: Decreased MUC1 expression induces E-cadherin-mediated cell adhesion of breast cancer cell lines. Cancer Res 1998, 58:2014-2019.

20. Schroeder JA, Masri AA, Adriance MC, Tessier JC, Kotlarczyk KL, Thompson MC, Gendler SJ: MUC1 overexpression results in mammary gland tumorigenesis and prolonged alveolar differentiation. Oncogene 2004, 23:5739-5747

21. van Amerongen $R$, Nusse R: Towards an integrated view of Wnt signaling in development. Development 2009, 136:3205-3214

22. McNeill H, Woodgett JR: When pathways collide: collaboration and connivance among signalling proteins in development. Nat Rev Mol Cell Biol 2010, 11:404-413.

23. Zeng YA, Nusse R: Wnt proteins are self-renewal factors for mammary stem cells and promote their long-term expansion in culture. Cell Stem Cell 2010, 6:568-577.

24. Ryo A, Nakamura M, Wulf G, Liou YC, Lu KP: Pin1 regulates turnover and subcellular localization of beta-catenin by inhibiting its interaction with APC. Nat Cell Bio/ 2001, 3:793-801.

25. Persad S, Troussard AA, McPhee TR, Mulholland DJ, Dedhar S: Tumor suppressor PTEN inhibits nuclear accumulation of beta-catenin and T cell/ lymphoid enhancer factor 1-mediated transcriptional activation. J Cell Biol 2001, 153:1161-1174.

26. Korkaya H, Paulson A, Charafe-Jauffret E, Ginestier C, Brown M, Dutcher J, Clouthier SG, Wicha MS: Regulation of mammary stem/progenitor cells by
PTEN/Akt/beta-catenin signaling. PLoS Bio/ 2009, 7:e1000121.

27. Sadot E, Geiger B, Oren M, Ben-Ze'ev A: Down-regulation of beta-catenin by activated p53. Mol Cell Bio/ 2001, 21:6768-6781.

28. Matsuzawa SI, Reed JC: Siah-1, SIP, and Ebi collaborate in a novel pathway for beta-catenin degradation linked to 553 responses. Mol Cell 2001, 7:915-926.

29. Liu J, Stevens J, Rote CA, Yost HJ, Hu Y, Neufeld KL, White RL, Matsunami N: Siah-1 mediates a novel beta-catenin degradation pathway linking p53 to the adenomatous polyposis coli protein. Mol Cell 2001, 7:927-936.

30. Patturajan M, Nomoto S, Sommer M, Fomenkov A, Hibi K, Zangen R, Poliak N, Califano J, Trink B, Ratovitski E, Sidransky D: DeltaNp63 induces beta-catenin nuclear accumulation and signaling. Cancer Cell 2002, 1:369-379.

31. Lamberti C, Lin KM, Yamamoto Y, Verma U, Verma IM, Byers S, Gaynor RB: Regulation of beta-catenin function by the IkB kinases. J Biol Chem 2001 276:42276-42286.

32. Stingl J, Eirew P, Ricketson I, Shackleton M, Vaillant F, Choi D, Li HI, Eaves CJ: Purification and unique properties of mammary epithelial stem cells. Nature 2006, 439:993-997.

33. Shackleton M, Vaillant F, Simpson KJ, Stingl J, Smyth GK, Asselin-Labat ML, Wu L, Lindeman GJ, Visvader JE: Generation of a functional mammary gland from a single stem cell. Nature 2006, 439:84-88.

34. Badders NM, Goel S, Clark RJ, Klos KS, Kim S, Bafico A, Lindvall C, Williams BO, Alexander CM: The Wnt receptor, Lrp5, is expressed by mouse mammary stem cells and is required to maintain the basal lineage. PLoS One 2009, 4:e6594.

35. Cowin P, Wysolmerski J: Molecular mechanisms guiding embryonic mammary gland development. Cold Spring Harb Perspect Biol 2010, 2:a003251

36. Chu EY, Hens J, Andl T, Kairo A, Yamaguchi TP, Brisken C, Glick A, Wysolmerski J, Millar SE: Canonical WNT signaling promotes mammary placode development and is essential for initiation of mammary gland morphogenesis. Development 2004, 131::4819-4829.

37. van Genderen C, Okamura RM, Farinas I, Quo R-G, Parslow TG, Bruhn L, Grosschedl R: Development of several organs that require inductive epithelial-mesenchymal interactions is impaired in Lef- 1 deficient mice. Genes and Development 1994, 8:2691-2704.

38. Gu B, Sun P, Yuan Y, Moraes RC, Li A, Teng A, Agrawal A, Rheaume C, Bilanchone V, Veltmaat JM, Takemaru K, Millar S, Lee EY, Lewis MT, Li B, Dai X: Pygo2 expands mammary progenitor cells by facilitating histone $\mathrm{H} 3 \mathrm{~K} 4$ methylation. J Cell Biol 2009, 185:811-826.

39. Lindvall C, Evans NC, Zylstra CR, Li Y, Alexander CM, Williams BO: The Wnt signaling receptor Lrp5 is required for mammary ductal stem cell activity and Wnt1-induced tumorigenesis. J Biol Chem 2006, 281:35081-35087.

40. Lindvall C, Zylstra CR, Evans N, West RA, Dykema K, Furge KA, Williams BO: The Wnt co-receptor Lrp6 is required for normal mouse mammary gland development. PLoS One 2009, 4:e5813.

41. Cho KW, Kim JY, Song SJ, Farrell E, Eblaghie MC, Kim HJ, Tickle C, Jung HS Molecular interactions between Tbx3 and Bmp4 and a model for dorsoventral positioning of mammary gland development. Proc Natl Acad SciUSA 2006, 103:16788-16793.

42. Veltmaat JM, Relaix F, Le LT, Kratochwil K, Sala FG, van Veelen W, Rice R, Spencer-Dene B, Mailleux AA, Rice DP, Thiery JP, Bellusci S: Gli3-mediated somitic Fgf10 expression gradients are required for the induction and patterning of mammary epithelium along the embryonic axes. Development 2006, 133:2325-2335

43. Mailleux AA, Spencer-Dene B, Dillon C, Ndiaye D, Savona-Baron C, Itoh N, Kato S, Dickson C, Thiery JP, Bellusci S: Role of FGF10/FGFR2b signaling during mammary gland development in the mouse embryo. Development 2002, 129:53-60

44. Jerome-Majewska LA, Jenkins GP, Ernstoff E, Zindy F, Sherr CJ, Papaioannou VE: Tbx3, the ulnar-mammary syndrome gene, and Tbx2 interact in mammary gland development through a p19Arf/p53-independent pathway. Dev Dyn 2005, 234:922-933.

45. Davenport TG, Jerome-Majewska LA, Papaioannou VE: Mammary gland limb and yolk sac defects in mice lacking Tbx3, the gene mutated in human ulnar mammary syndrome. Development 2003, 130:2263-2273.

46. Howard B, Panchal H, McCarthy A, Ashworth A: Identification of the scaramanga gene implicates Neuregulin3 in mammary gland specification. Genes Dev 2005, 19:2078-2090.

47. Eblaghie MC, Song SJ, Kim JY, Akita K, Tickle C, Jung HS: Interactions between FGF and Wnt signals and Tbx3 gene expression in mammary 
gland initiation in mouse embryos. J Anat 2004, 205:1-13.

48. Veltmaat JM, Van Veelen W, Thiery JP, Bellusci S: Identification of the mammary line in mouse by Wnt $10 \mathrm{~b}$ expression. Dev Dyn 2004, 229:349-356.

49. Pummila M, Fliniaux I, Jaatinen R, James MJ, Laurikkala J, Schneider P, Thesleff I, Mikkola ML: Ectodysplasin has a dual role in ectodermal organogenesis: inhibition of Bmp activity and induction of Shh expression. Development 2007, 134:117-125.

50. Boras-Granic K, Chang H, Grosschedl R, Hamel PA: Lef1 is required for the transition of Wnt signaling from mesenchymal to epithelial cells in the mouse embryonic mammary gland. Dev Biol 2006, 295:219-231.

51. Abdalkhani A, Sellers R, Gent J, Wulitich H, Childress S, Stein B, Boissy RE, Wysolmerski JJ, Foley J: Nipple connective tissue and its development: insights from the K14-PTHrP mouse. Mech Dev 2002, 115:63-77.

52. Dunbar ME, Dann PR, Robinson GW, Hennighausen L, Zhang JP, Wysolmersk $\mathrm{JJ}$ : Parathyroid hormone-related protein signaling is necessary for sexual dimorphism during embryonic mammary development. Development 1999, 126:3485-3493.

53. Foley J, Dann P, Hong J, Cosgrove J, Dreyer B, Rimm D, Dunbar M, PhilbrickW, Wysolmerski J: Parathyroid hormone-related protein maintains mammary epithelial fate and triggers nipple skin differentiation during embryonic breast development. Development 2001, 128:513-525.

54. Hens JR, Dann P, Zhang JP, Harris S, Robinson GW, Wysolmerski J: BMP4 and PTHrP interact to stimulate ductal outgrowth during embryonic mammary development and to inhibit hair follicle induction. Development 2007, 134:1221-1230.

55. Wysolmerski JJ, McCaughern-Carucci JF, Daifotis AG, Broadus AE, Philbrick WM: Overexpression of parathyroid hormone-related protein or parathyroid hormone in transgenic mice impairs branching morphogenesis during mammary gland development. Development 1995, 121:3539-3547.

56. Wysolmerski JJ, Philbrick WM, Dunbar ME, Lanske B, Kronenberg H, Broadus $A E:$ Rescue of the parathyroid hormone-related protein knockout mouse demonstrates that parathyroid hormone-related protein is essential for mammary gland development. Development 1998, 125:1285-1294.

57. Hens J, Dann P, Hiremath M, Pan TC, Chodosh L, Wysolmerski J: Analysis of gene expression in PTHrP $\mathrm{P}^{-/-}$mammary buds supports a role for BMP signaling and MMP2 in the initiation of ductal morphogenesis. Dev Dyn 2009, 238:2713-2724.

58. Bradbury JM, Edwards PA, Niemeyer CC, Dale TC: Wnt-4 expression induces a pregnancy-like growth pattern in reconstituted mammary glands in virgin mice. Dev Biol 1995, 170:553-563.

59. Weber-Hall SJ, Phippard DJ, Niemeyer CC, Dale TC: Developmental and hormonal regulation of Wnt gene expression in the mouse mammary gland. Differentiation 1994, 57:205-214.

60. Buhler TA, Dale TC, Kieback C, Humphreys RC, Rosen JM: Localization and quantification of Wnt-2 gene expression in mouse mammary development. Dev Biol 1993, 155:87-96.

61. Lane TF, Leder P: Wnt10B directs hypermorphic development and transformation in mammary glands of male and female mice. Oncogene 1997, 15:2133-2144.

62. Lustig B, Jerchow B, Sachs M, Weiler S, Pietsch T, Karsten U, van de Wetering M, Clevers H, Schlag PM, Birchmeier W, Behrens J: Negative feedback loop of Wnt signaling through upregulation of conductin/axin2 in colorectal and liver tumors. Mol Cell Bio/ 2002, 22:1184-1193.

63. Kouros-Mehr H, Werb Z: Candidate regulators of mammary branching morphogenesis identified by genome-wide transcript analysis. Dev Dyn 2006, 235:3404-3412.

64. Roarty K, Serra R: Wnt5a is required for proper mammary gland development and TGF- $\beta$-mediated inhibition of ductal growth. Development 2007, 134:3929-3939.

65. Ismail PM, Li J, DeMayo FJ, O'Malley BW, Lydon JP: A novel LacZ reporter mouse reveals complex regulation of the progesterone receptor promoter during mammary gland development. Mol Endocrinol 2002, 16:2475-2489.

66. Hiremath M, Lydon JP, Cowin P: The pattern of beta-catenin responsiveness within the mammary gland is regulated by progesterone receptor. Development 2007, 134:3703-3712.

67. Teissedre B, Pinderhughes A, Incassati A, Hatsell SJ, Hiremath M, Cowin P: MMTV-Wnt1 and - $\triangle$ N89 $\beta$-catenin induce canonical signaling in distinct progenitors and differentially activate Hedgehog signaling within mammary tumors. PLoS One 2009, 4:e4537.
68. Brisken C, Park S, Vass T, Lydon JP, O'Malley BW, Weinberg RA: A paracrine role for the epithelial progesterone receptor in mammary gland development. Proc Natl Acad Sci U S A 1998, 95:5076-5081.

69. Brisken C, Heineman A, Chavarra T, Elenbaas B, Tan J, Dey SK, McMahon AP, Weinberg R: Essential function of Wnt-4 in mammary gland development downstream of progesterone signaling. Genes Dev 2000, 14:650-654.

70. Schramek D, Leibbrandt A, Sigl V, Kenner L, Pospisilik JA, Lee HJ, Hanada R, Joshi P, Aliprantis A, Glimcher L, Pasparakis M, Khokha R, Ormandy CJ, Widschwendter M, Schett G, Penninger JM: Osteoclast differentiation factor RANKL controls development of progestin-driven mammary cancer. Nature 2010, in press.

71. Joshi PA, Jackson HW, Beristain AG, Di Grappa MA, Mote PA, Clarke CL, Stingl J, Waterhouse PD, Khokha R: Progesterone induces adult mammary stem cell expansion. Nature 2010, 465:803-807.

72. Kim YC, Clark RJ, Pelegri F, Alexander CM: Wnt4 is not sufficient to induce lobuloalveolar mammary development. BMC Dev Bio/ 2009, 9:55.

73. Chadi S, Buscara L, Pechoux C, Costa J, Laubier J, Chaboissier MC, Pailhoux E, Vilotte JL, Chanat E, Le Provost F: R-spondin 1 is required for normal epithelial morphogenesis during mammary gland development. Biochem Biophys Res Commun 2009, 390:1040-1043.

74. Teuliere J, Faraldo MM, Deugnier MA, Shtutman M, Ben-Ze'ev A, Thiery JP, Glukhova MA: Targeted activation of beta-catenin signaling in basal mammary epithelial cells affects mammary development and leads to hyperplasia. Development 2005, 132:267-277.

75. Imbert A, Eelkema R, Jordan S, Feiner H, Cowin P: $\triangle N 89 \beta$-catenin induces precocious development, differentiation, and neoplasia in mammary gland. J Cell Biol 2001, 153:555-568.

76. Hsu W, Shakya R, Costantini F: Impaired mammary gland and lymphoid development caused by inducible expression of Axin in transgenic mice. J Cell Bio/ 2001, 155:1055-1064

77. Tepera SB, McCrea PD, Rosen JM: A beta-catenin survival signal is required for normal lobular development in the mammary gland. J Cell Sci 2003, 116(Pt 6):1137-1149.

78. Fata JE, Kong YY, Li J, Sasaki T, Irie-Sasaki J, Moorehead RA, Elliott R, Scully S, Voura EB, Lacey DL, Boyle WJ, Khokha R, Penninger JM: The osteoclast differentiation factor osteoprotegerin-ligand is essential for mammary gland development. Cell 2000, 103:41-50.

79. Beleut M, Rajaram RD, Caikovski M, Ayyanan A, Germano D, Choi Y, Schneider $P$, Brisken C: Two distinct mechanisms underlie progesterone-induced proliferation in the mammary gland. Proc Natl Acad Sci U S A 2010, 107:2989-2994.

80. Liou YC, Ryo A, Huang HK, Lu PJ, Bronson R, Fujimori F, Uchida T, Hunter T, Lu KP: Loss of Pin 1 function in the mouse causes phenotypes resembling cyclin D,-null phenotypes. Proc Natl Acad Sci U S A 2002, 99:1335-1340.

81. Yu Q, Geng Y, Sicinski P: Specific protection against breast cancers by cyclin D ablation. Nature 2001, 411:1017-1021.

82. Rowlands TM, Pechenkina IV, Hatsell SJ, Pestell RG, Cowin P: Dissecting the roles of beta-catenin and cyclin $D_{1}$ during mammary development and neoplasia. Proc Natl Acad Sci U S A 2003, 100:11400-11405.

83. Nusse R, Varmus HE: Many tumors induced by the mouse mammary tumor virus contain a provirus integrated in the same region of the host genome. Cell 1982, 31:99-109.

84. Tsukamoto A, Grosschedl R, Guzman R, Parslow T, Varmus H: Expression of the int- 1 gene in transgenic mice is associated with mammary gland hyperplasia and adenocarcinomas in male and female mice. Cell 1988, 55:619-625.

85. Li Y, Welm B, Podsypanina K, Huang S, Chamorro M, Zhang X, Rowlands T, Egeblad M, Cowin P, Werb Z, Tan LK, Rosen JM, Varmus HE: Evidence that transgenes encoding components of the Wnt signaling pathway preferentially induce mammary cancers from progenitor cells. Proc Natl Acad SciU S A 2003, 100:15853-15858.

86. Liu BY, Kim YC, Leatherberry V, Cowin P, Alexander CM: Mammary gland development requires syndecan-1 to create a beta-catenin/TCFresponsive mammary epithelial subpopulation. Oncogene 2003, 22:9243-9253

87. Liu BY, McDermott SP, Khwaja SS, Alexander CM: The transforming activity of Wnt effectors correlates with their ability to induce the accumulation of mammary progenitor cells. Proc Natl Acad Sci U S A 2004, 101:4158-4163.

88. Zhang J, Li Y, Liu Q, Lu W, Bu G: Wnt signaling activation and mammary gland hyperplasia in MMTV-LRP6 transgenic mice: implication for breast cancer tumorigenesis. Oncogene 2010, 29:539-549. 
89. Gunther EJ, Moody SE, Belka GK, Hahn KT, Innocent N, Dugan KD, Cardiff RD, Chodosh LA: Impact of p53 loss on reversal and recurrence of conditional Wnt-induced tumorigenesis. Genes Dev 2003, 17:488-501.

90. Michaelson JS, Leder P: $\beta$-catenin is a downstream effector of Wntmediated tumorigenesis in the mammary gland. Oncogene 2001, 20:5093-5099.

91. Rowlands TM, Pechenkina IV, Hatsell S, Cowin P: Beta-catenin and cyclin $D_{1}$ : connecting development to breast cancer. Cell Cycle 2004, 3:145-148.

92. Woodward WA, Chen MS, Behbod F, Alfaro MP, BuchholzTA, Rosen JM: WNT/ beta-catenin mediates radiation resistance of mouse mammary progenitor cells. Proc Natl Acad Sci U S A 2007, 104:618-623.

93. Miyoshi K, Shillingford JM, Le Provost F, Gounari F, Bronson R, von Boehmer H, Taketo MM, Cardiff RD, Hennighausen L, Khazaie K: Activation of betacatenin signaling in differentiated mammary secretory cells induces transdifferentiation into epidermis and squamous metaplasias. Proc Natl Acad Sci U S A 2002, 99:219-224

94. Kuraguchi M, Ohene-Baah NY, Sonkin D, Bronson RT, Kucherlapati R: Genetic mechanisms in Apc-mediated mammary tumorigenesis. PLoS Genet 2009, 5:e1000367.

95. Gaspar C, Franken P, Molenaar L, Breukel C, van der Valk M, Smits R, Fodde R: A targeted constitutive mutation in the APC tumor suppressor gene underlies mammary but not intestinal tumorigenesis. PLoS Genet 2009, 5:e1000547.

96. Wang H, Teske D, Tess A, Kohlhepp R, Choi Y, Kendziorski C, Moser AR: Identification of novel modifier loci of Apc Min affecting mammary tumor development. Cancer Res 2007, 67:11226-11233.

97. Roarty K, Baxley SE, Crowley MR, Frost AR, Serra R: Loss of TGF- $\beta$ or Wnt5a results in an increase in Wnt/beta-catenin activity and redirects mammary tumour phenotype. Breast Cancer Res 2009, 11:R19.

98. Kim YC, Clark RJ, Ranheim EA, Alexander CM: Wnt1 expression induces short-range and long-range cell recruitments that modify mammary tumor development and are not induced by a cell-autonomous betacatenin effector. Cancer Res 2008, 68:10145-10153.

99. Cho RW, Wang X, Diehn M, Shedden K, Chen GY, Sherlock G, Gurney A, Lewicki J, Clarke MF: Isolation and molecular characterization of cancer stem cells in MMTV-Wnt-1 murine breast tumors. Stem Cells 2008, 26:364-371

100. DiMeo TA, Anderson K, Phadke P, Fan C, Perou CM, Naber S, Kuperwasser C: A novel lung metastasis signature links Wnt signaling with cancer cell self-renewal and epithelial-mesenchymal transition in basal-like breast cancer. Cancer Res 2009, 69:5364-5373.

101. Khramtsov Al, Khramtsova GF, Tretiakova M, Huo D, Olopade Ol, Goss KH: Wnt/beta-catenin pathway activation is enriched in basal-like breast cancers and predicts poor outcome. Am J Pathol 2010, 176:2911-2920.

102. Liu CC, Prior J, Piwnica-Worms D, Bu G: LRP6 overexpression defines a class of breast cancer subtype and is a target for therapy. Proc Natl Acad Sci U S A 2010, 107:5136-5141.

103. Herschkowitz JI, Simin K, Weigman VJ, Mikaelian I, Usary J, Hu Z, Rasmussen KE, Jones LP, Assefnia S, Chandrasekharan S, Backlund MG, Yin Y, Khramtsov Al, Bastein R, Quackenbush J, Glazer RI, Brown PH, Green JE, Kopelovich L, Furth PA, Palazzo JP, Olopade OI, Bernard PS, Churchill GA, Van Dyke T, Perou $C M$ : Identification of conserved gene expression features between murine mammary carcinoma models and human breast tumors. Genome Bio/ 2007, 8:R76.

104. Sawyer EJ, Hanby AM, Rowan AJ, Gillett CE, Thomas RE, Poulsom R, Lakhani SR, Ellis IO, Ellis P, Tomlinson IP: The Wnt pathway, epithelial-stromal interactions, and malignant progression in phyllodes tumours. J Pathol 2002, 196:437-444

105. Abraham SC, Reynolds C, Lee JH, Montgomery EA, Baisden BL, Krasinskas AM, Wu TT: Fibromatosis of the breast and mutations involving the APC/betacatenin pathway. Hum Pathol 2002, 33:39-46.

106. Hayes MJ, Thomas D, Emmons A, Giordano TJ, Kleer CG: Genetic changes of Wnt pathway genes are common events in metaplastic carcinomas of the breast. Clin Cancer Res 2008, 14:4038-4044.

107. Lin SY, Xia W, Wang JC, Kwong KY, Spohn B, Wen Y, Pestell RG, Hung MC: Beta-catenin, a novel prognostic marker for breast cancer: its roles in cyclin D expression and cancer progression. Proc Natl Acad Sci U S A 2000, 97:4262-4266.

108. Jonsson M, Borg A, Nilbert M, Andersson T: Involvement of adenomatous polyposis coli (APC)/beta-catenin signalling in human breast cancer. Eur J Cancer 2000, 36:242-248.
109. Ozaki S, Ikeda S, Ishizaki Y, Kurihara T, Tokumoto N, Iseki M, Arihiro K, Kataoka T, Okajima M, Asahara T: Alterations and correlations of the components in the Wnt signaling pathway and its target genes in breast cancer. Oncol Rep 2005, 14:1437-1443.

110. Sormunen RT, Leong AS, Vaaraniemi JP, Fernando SS, Eskelinen SM: Immunolocalization of the fodrin, E-cadherin, and beta-catenin adhesion complex in infiltrating ductal carcinoma of the breast-comparison with an in vitro model. J Pathol 1999, 187:416-423.

111. Karayiannakis AJ, Nakopoulou L, Gakiopoulou H, Keramopoulos A, Davaris PS, Pignatelli M: Expression patterns of beta-catenin in in situ and invasive breast cancer. Eur J Surg Oncol 2001, 27:31-36.

112. Wong SC, Lo SF, Lee KC, Yam JW, Chan JK, Wendy Hsiao WL: Expression of frizzled-related protein and Wnt-signalling molecules in invasive human breast tumours. J Patho/ 2002, 196:145-153.

113. Prasad CP, Gupta SD, Rath G, Ralhan R: Wnt signaling pathway in invasive ductal carcinoma of the breast: relationship between beta-catenin, dishevelled and cyclin D, expression. Oncology 2007, 73:112-117.

114. Prasad CP, Mirza S, Sharma G, Prashad R, DattaGupta S, Rath G, Ralhan R: Epigenetic alterations of $\mathrm{CDH} 1$ and APC genes: relationship with activation of Wnt/beta-catenin pathway in invasive ductal carcinoma of breast. Life Sci 2008, 83:318-325.

115. Wissmann C, Wild PJ, Kaiser S, Roepcke S, Stoehr R, Woenckhaus M, Kristiansen G, Hsieh JC, Hofstaedter F, Hartmann A, Knuechel R, Rosenthal A, Pilarsky C: WIF1, a component of the Wnt pathway, is down-regulated in prostate, breast, lung, and bladder cancer. J Patho/ 2003, 201:204-212.

116. Ugolini F, Charafe-Jauffret E, Bardou VJ, Geneix J, Adelaide J, Labat-Moleur F, Penault-Llorca F, Longy M, Jacquemier J, Birnbaum D, Pebusque MJ: WNT pathway and mammary carcinogenesis: loss of expression of candidate tumor suppressor gene SFRP1 in most invasive carcinomas except of the medullary type. Oncogene 2001, 20:5810-5817.

117. Shulewitz M, Soloviev I, Wu T, Koeppen H, Polakis P, Sakanaka C: Repressor roles for TCF-4 and Sfrp1 in Wnt signaling in breast cancer. Oncogene 2006, 25:4361-4369.

118. Ai L, Tao Q, Zhong S, Fields CR, Kim WJ, Lee MW, Cui Y, Brown KD, Robertson KD: Inactivation of Wnt inhibitory factor-1 (WIF1) expression by epigenetic silencing is a common event in breast cancer. Carcinogenesis 2006, 27:1341-1348.

119. Matsuda Y, Schlange T, Oakeley EJ, Boulay A, Hynes NE: WNT signaling enhances breast cancer cell motility and blockade of the WNT pathway by sFRP1 suppresses MDA-MB-231 xenograft growth. Breast Cancer Res 2009, 11:R32.

120. Gauger KJ, Hugh JM, Troester MA, Schneider SS: Down-regulation of sfrp1 in a mammary epithelial cell line promotes the development of a cd44high/ cd24low population which is invasive and resistant to anoikis. Cancer Cell Int 2009, 9:11.

121. Yang ZQ, Liu G, Bollig-Fischer A, Haddad R, Tarca AL, Ethier SP: Methylationassociated silencing of SFRP1 with an 8p11-12 amplification inhibits canonical and non-canonical WNT pathways in breast cancers. Int $J$ Cancer 2009, 125:1613-1621.

122. Veeck J, Niederacher D, An H, Klopocki E, Wiesmann F, Betz B, Galm O, Camara O, Durst M, Kristiansen G, Huszka C, Knuchel R, Dahl E: Aberrant methylation of the Wnt antagonist SFRP1 in breast cancer is associated with unfavourable prognosis. Oncogene 2006, 25:3479-3488.

123. Veeck J, Geisler C, Noetzel E, Alkaya S, Hartmann A, Knuchel R, Dahl E: Epigenetic inactivation of the secreted frizzled-related protein-5 (SFRP5) gene in human breast cancer is associated with unfavorable prognosis. Carcinogenesis 2008, 29:991-998.

124. Veeck J, Wild PJ, Fuchs T, Schuffler PJ, Hartmann A, Knuchel R, Dahl E: Prognostic relevance of Wnt-inhibitory factor-1 (WIF1) and Dickkopf-3 (DKK3) promoter methylation in human breast cancer. BMC Cancer 2009, 9:217.

125. Suzuki H, Toyota M, Carraway H, Gabrielson E, Ohmura T, Fujikane T, Nishikawa N, Sogabe Y, Nojima M, Sonoda T, Mori M, Hirata K, Imai K, Shinomura Y, Baylin SB, Tokino T: Frequent epigenetic inactivation of Wnt antagonist genes in breast cancer. Br J Cancer 2008, 98:1147-1156.

126. Forget MA, Turcotte S, Beauseigle D, Godin-Ethier J, Pelletier S, Martin J, Tanguay S, Lapointe R: The Wnt pathway regulator DKK1 is preferentially expressed in hormone-resistant breast tumours and in some common cancer types. Br J Cancer 2007, 96:646-653.

127. Kirikoshi $H$, Sekihara H, Katoh M: Expression of WNT14 and WNT14B mRNAs in human cancer, up-regulation of WNT14 by IFNy and up-regulation of 
WNT14B by beta-estradiol. Int J Oncol 2001, 19:1221-1225.

128. Huguet EL, McMahon JA, McMahon AP, Bicknell R, Harris AL: Differential expression of human Wnt genes 2, 3, 4, and 7B in human breast cell lines and normal and disease states of human breast tissue. Cancer Res 1994, 54:2615-2621.

129. Dale TC, Weber-Hall SJ, Smith K, Huguet EL, Jayatilake H, Gusterson BA, Shuttleworth G, O'Hare M, Harris AL: Compartment switching of Wnt-2 expression in human breast tumors. Cancer Res 1996, 56:4320-4323.

130. Benhaj K, Akcali KC, Ozturk M: Redundant expression of canonical Wnt ligands in human breast cancer cell lines. Oncol Rep 2006, 15:701-707.

131. Lejeune S, Huguet EL, Hamby A, Poulsom R, Harris AL: Wnt5a cloning expression, and up-regulation in human primary breast cancers. Clin Cancer Res 1995, 1:215-222.

132. Katoh M: Frequent up-regulation of WNT2 in primary gastric cancer and colorectal cancer. Int J Oncol 2001, 19:1003-1007.

133. Bui TD, Rankin J, Smith K, Huguet EL, Ruben S, Strachan T, Harris AL, Lindsay S: A novel human Wnt gene, WNT10B, maops to $12 q 13$ and is expressed in human breast carcinomas. Oncogene 1997, 14:1249-1253.

134. Watanabe O, Imamura H, Shimizu T, Kinoshita J, Okabe T, Hirano A, Yoshimatsu K, Konno S, Aiba M, Ogawa K: Expression of twist and wnt in human breast cancer. Anticancer Res 2004, 24:3851-3856.

135. Jonsson M, Dejmek J, Bendahl PO, Andersson T: Loss of Wnt-5a protein is associated with early relapse in invasive ductal breast carcinomas. Cancer Res 2002, 62:409-416.

136. Milovanovic T, Planutis K, Nguyen A, Marsh JL, Lin F, Hope C, Holcombe RF: Expression of Wnt genes and frizzled 1 and 2 receptors in normal breast epithelium and infiltrating breast carcinoma. Int J Oncol 2004 25:1337-1342

137. Bjorklund P, Svedlund J, Olsson AK, Akerstrom G, Westin G: The internally truncated LRP5 receptor presents a therapeutic target in breast cancer. PLoS One 2009, 4:e4243.

138. Nagahata T, Shimada T, Harada A, Nagai H, Onda M, Yokoyama S, Shiba T, Jin E, Kawanami O, Emi M: Amplification, up-regulation and over-expression of DVL-1, the human counterpart of the Drosophila disheveled gene, in primary breast cancers. Cancer Sci 2003, 94:515-518.

139. Sorlie T, Bukholm I, Borresen-Dale AL: Truncating somatic mutation in exon 15 of the APC gene is a rare event in human breast carcinomas. Mutations in brief no. 179. Online. Hum Mutat 1998, 12:215-216.

140. Schlosshauer PW, Brown SA, Eisinger K, Yan Q, Guglielminetti ER, Parsons R Ellenson LH, Kitajewski J: APC truncation and increased beta-catenin levels in a human breast cancer cell line. Carcinogenesis 2000, 21:1453-1456.

141. Furuuchi K, Tada M, Yamada H, Kataoka A, Furuuchi N, Hamada J, Takahashi M, Todo S, Moriuchi T: Somatic mutations of the APC gene in primary breast cancers. Am J Patho/ 2000, 156:1997-2005.

142. Wang X, Goode EL, Fredericksen ZS, Vierkant RA, Pankratz VS, Liu-Mares W, Rider DN, Vachon CM, Cerhan JR, Olson JE, Couch FJ: Association of genetic variation in genes implicated in the beta-catenin destruction complex with risk of breast cancer. Cancer Epidemiol Biomarkers Prev 2008, 17:2101-2108.

143. Thompson AM, Morris RG, Wallace M, Wyllie AH, Steel CM, Carter DC: Allele loss from 5q21 (APC/MCC) and 18q21 (DCC) and DCC mRNA expression in breast cancer. Br J Cancer 1993, 68:64-68.

144. Sarrio D, Moreno-Bueno G, Hardisson D, Sanchez-Estevez C, Guo M, Herman JG, Gamallo C, Esteller M, Palacios J: Epigenetic and genetic alterations of APC and $\mathrm{CDH} 1$ genes in lobular breast cancer: relationships with abnormal E-cadherin and catenin expression and microsatellite instability. Int J Cancer 2003, 106:208-215.

145. Kashiwaba M, Tamura G, Ishida M: Aberrations of the APC gene in primary breast carcinoma. J Cancer Res Clin Oncol 1994, 120:727-731.

146. Medeiros AC, Nagai MA, Neto MM, Brentani RR: Loss of heterozygosity affecting the APC and MCC genetic loci in patients with primary breast carcinomas. Cancer Epidemiol Biomarkers Prev 1994, 3:331-333.

147. Ho KY, Kalle WH, Lo TH, Lam WY, Tang CM: Reduced expression of APC and DCC gene protein in breast cancer. Histopathology 1999, 35:249-256.

148. Webster MT, Rozycka M, Sara E, Davis E, Smalley M, Young N, Dale TC, Wooster $R$ : Sequence variants of the axin gene in breast, colon, and other cancers: an analysis of mutations that interfere with GSK3 binding. Genes Chromosomes Cancer 2000, 28:443-453.

149. Jin Z, Tamura G, Tsuchiya T, Sakata K, Kashiwaba M, Osakabe M, Motoyama T: Adenomatous polyposis coli (APC) gene promoter hypermethylation in primary breast cancers. Br J Cancer 2001, 85:69-73.
150. Virmani AK, Rathi A, Sathyanarayana UG, Padar A, Huang CX, Cunnigham HT, Farinas AJ, Milchgrub S, Euhus DM, Gilcrease M, Herman J, Minna JD, Gazdar AF: Aberrant methylation of the adenomatous polyposis coli (APC) gene promoter 1A in breast and lung carcinomas. Clin Cancer Res 2001, 7:1998-2004.

151. Roh MS, Hong SH, Jeong JS, Kwon HC, Kim MC, Cho SH, Yoon JH, Hwang TH: Gene expression profiling of breast cancers with emphasis of beta-catenin regulation. J Korean Med Sci 2004, 19:275-282

152. Van der Auwera I, Van Laere SJ, Van den Bosch SM, Van den Eynden GG, Trinh BX, van Dam PA, Colpaert CG, van Engeland M, Van Marck EA, Vermeulen PB, Dirix LY: Aberrant methylation of the adenomatous polyposis coli (APC) gene promoter is associated with the inflammatory breast cancer phenotype. Br J Cancer 2008, 99:1735-1742.

153. Andrews PG, Lake BB, Popadiuk C, Kao KR: Requirement of Pygopus 2 in breast cancer. Int J Oncol 2007, 30:357-363.

154. Shi B, Liang J, Yang X, Wang Y, Zhao Y, Wu H, Sun L, Zhang Y, Chen Y, Li R, Zhang $Y$, Hong M, Shang $Y$ : Integration of estrogen and Wnt signaling circuits by the polycomb group protein $\mathrm{EZH} 2$ in breast cancer cells. Mol Cell Biol 2007, 27:5105-5119.

155. Aulmann S, Bentz M, Sinn HP: C-myc oncogene amplification in ductal carcinoma in situ of the breast. Breast Cancer Res Treat 2002, 74:25-31.

156. Gillett C, Fantl V, Smith R, Fisher C, Bartek J, Dickson C, Barnes D, Peters G: Amplification and overexpression of cyclin $D_{1}$ in breast cancer detected by immunohistochemical staining. Cancer Res 1994, 54:1812-1817.

157. Musgrove EA, Hui R, Sweeney KJ, Watts CK, Sutherland RL: Cyclins and breast cancer. J Mammary Gland Bio/ Neoplasia 1996, 1:153-162.

158. Bieche I, Laurendeau I, Tozlu S, Olivi M, Vidaud D, Lidereau R, Vidaud M: Quantitation of MYC gene expression in sporadic breast tumors with a real-time reverse transcription-PCR assay. Cancer Res 1999, 59:2759-2765.

159. Cowling VH, D'Cruz CM, Chodosh LA, Cole MD: c-Myc transforms human mammary epithelial cells through repression of the Wnt inhibitors DKK1 and SFRP1. Mol Cell Biol 2007, 27:5135-5146.

160. Xu L, Corcoran RB, Welsh JW, Pennica D, Levine AJ: WISP-1 is a Wnt-1- and beta-catenin-responsive oncogene. Genes Dev 2000, 14:585-595.

161. Xie D, Nakachi K, Wang H, Elashoff R, Koeffler HP: Elevated levels of connective tissue growth factor, WISP-1, and CYR61 in primary breast cancers associated with more advanced features. Cancer Res 2001 61:8917-8923

162. Fu DY, Wang ZM, Li C, Wang BL, Shen ZZ, Huang W, Shao ZM: Sox17, the canonical Wnt antagonist, is epigenetically inactivated by promoter methylation in human breast cancer. Breast Cancer Res Treat 2010, 119:601-612

163. Rieger ME, Sims AH, Coats ER, Clarke RB, Briegel KJ: The embryonic transcription cofactor LBH is a direct target of the WNT signaling pathway in epithelial development and in aggressive basal subtype breast cancers. Mol Cell Biol 2010, 30:4267-4279.

164. Wulf GM, Ryo A, Wulf GG, Lee SW, Niu T, Petkova V, Lu KP: Pin1 is overexpressed in breast cancer and cooperates with Ras signaling in increasing the transcriptional activity of c-Jun towards cyclin $D_{1}$. EMBO J 2001, 20:3459-3472.

165. Biswas DK, Shi Q, Baily S, Strickland I, Ghosh S, Pardee AB, Iglehart JD: NF-kB activation in human breast cancer specimens and its role in cell proliferation and apoptosis. Proc Natl Acad Sci U S A 2004, 101:10137-10142.

166. Farooq A, Walker LJ, Bowling J, Audisio RA: Cowden syndrome. Cancer Treat Rev 2010. [Epub ahead of print]

167. Depowski PL, Rosenthal SI, Ross JS: Loss of expression of the PTEN gene protein product is associated with poor outcome in breast cancer. Mod Pathol 2001, 14:672-676.

168. Zhao H, Cui Y, Dupont J, Sun H, Hennighausen L, Yakar S: Overexpression of the tumor suppressor gene phosphatase and tensin homologue partially inhibits wnt-1-induced mammary tumorigenesis. Cancer Res 2005 65:6864-6873.

169. Lee JY, Kang MB, Jang SH, Qian T, Kim HJ, Kim CH, Kim Y, Kong G: Id-1 activates Akt-mediated Wnt signaling and p27(Kip1) phosphorylation through PTEN inhibition. Oncogene 2009, 28:824-831.

170. Prasad A, Paruchuri V, Preet A, Latif F, Ganju RK: Slit-2 induces a tumorsuppressive effect by regulating beta-catenin in breast cancer cells. J Biol Chem 2008, 283:26624-26633.

171. Mhashilkar AM, Stewart AL, Sieger K, Yang HY, Khimani AH, Ito I, Saito Y, Hunt KK, Grimm EA, Roth JA, Meyn RE, Ramesh R, Chada S: MDA-7 negatively regulates the beta-catenin and $\mathrm{PI} 3 \mathrm{~K}$ signaling pathways in breast and 
lung tumor cells. Mol Ther 2003, 8:207-219.

172. Gasco M, Shami S, CrookT: The p53 pathway in breast cancer. Breast Cancer Res 2002, 4:70-76

173. Mei Y, Xie C, Xie W, Wu Z, Wu M: Siah-1S, a novel splice variant of Siah-1 (seven in absentia homolog), counteracts Siah-1-mediated downregulation of beta-catenin. Oncogene 2007, 26:6319-6331.

174. Iwai A, Marusawa H, Matsuzawa S, Fukushima T, Hijikata M, Reed JC, Shimotohno K, Chiba T: Siah-1L, a novel transcript variant belonging to the human Siah family of proteins, regulates beta-catenin activity in a p53dependent manner. Oncogene 2004, 23:7593-7600.

175. Ridgeway AG, McMenamin J, Leder P: P53 levels determine outcome during beta-catenin tumor initiation and metastasis in the mammary gland and male germ cells. Oncogene 2006, 25:3518-3527.

176. Chung GG, Zerkowski MP, Ocal IT, Dolled-Filhart M, Kang JY, Psyrri A, Camp RL, Rimm DL: $\beta$-Catenin and p53 analyses of a breast carcinoma tissue microarray. Cancer 2004, 100:2084-2092.
177. Koker MM, Kleer CG: p63 expression in breast cancer: a highly sensitive and specific marker of metaplastic carcinoma. Am J Surg Pathol 2004, 28:1506-1512.

178. Moser AR, Mattes EM, Dove WF, Lindstrom MJ, Haag JD, Gould MN: ApcMin, a mutation in the murine Apc gene, predisposes to mammary carcinomas and focal alveolar hyperplasias. Proc Natl Acad Sci U S A 1993, 90:8977-8981.

179. Gallagher RC, Hay T, Meniel V, Naughton C, Anderson TJ, Shibata H, Ito M, Clevers H, Noda T, Sansom OJ, Mason JO, Clarke AR: Inactivation of Apc perturbs mammary development, but only directly results in acanthoma in the context of Tcf-1 deficiency. Oncogene 2002, 21:6446-6457.

doi:10.1186/bcr2723

Cite this article as: Incassati A, et al.: Key signaling nodes in mammary gland development and cancer: $\beta$-catenin. Breast Cancer Research 2010, 12:213. 